\title{
SPOTLIGHT ESSAY
}

\section{“THE PARENT I NEVER HAD": THE CONTEMPORARY CONSTRUCTION OF ALTERNATIVES TO INCARGERATION}

\author{
JOHN M. SLOOP
}

This essay is developed along two lines. First, I investigate contemporary arguments and public discussions from which the concept of "alternative punishments" is being constructed and speculate about the infuence of these constructions on how prisoners, laws, and morality are viewed publicly. I suggest that the current construction of alternatives to incarceration encourage all members of our culture to accept and encourage dominant definitions of "proper" behavior. Second, I use the essay as a representation of the utility of recent moves to incorporate poststructuralist themes into communication studies, most notably those emerging from the recent discussion of a "critical rhetoric."

Tn late 1987, after being convicted of drug possession and driving while intoxicated, Maria Arnford faced sentencing by Texas District Court Judge Ted Poe. Because prisons in Texas were filled beyond capacity as a result of recent legislation that lengthened sentences for virtually all crimes in the state, Arnford was sentenced to an alternative and experimental form of punishment. Arnford's home, in effect, was transformed into a mediated prison. A video screen, camera, and transmitter were installed in her house, and authorities could monitor her at all times to be sure that she was at "home." Further, Arnford was asked at random times to provide urine samples in order to prove that she was indeed following orders to abstain from drugs and alcohol throughout the length of her sentence. According to the conditions of her sentence, Arnford was only permitted to leave her house for preapproved therapy appointments, community service, or church meetings. The gaze of the "state" was constantly fixed upon Arnford, its probe monitoring not only her movements but even the composition of her blood. When asked her assessment of the sentence, Arnford stated that "This program has been like a parent to me, the parent I never had."1

Arnford's testimony, and that of others who have undergone alternative forms of punishment, or "smarter" punishment as it has recently been termed, has flooded the pages of newspapers and other popular publications with increasing regularity. ${ }^{2}$ These testimonies, and articles that discuss and debate alternative punishments, not only provide the public with information on these alternatives, but indeed "construct" the constitution of the "state," "criminals," and "law abiding citizens." 3 As jails and prisons continue to overflow due to increased pressure for "tougher" punishments for drug usage, drunk driving, and crimes in general, corrections departments are forced to turn to alternative forms of punishment. ${ }^{4}$ In this essay, I examine the public discourses that serve as the basis for the rhetorical construction of the concept of "alternative punishments," and speculate on the influence of this construction on our society's views of appropriate and effective criminal punishment. ${ }^{5}$ In doing so, this essay seeks to demonstrate the

John M. Sloop (Ph.D., University of Iowa, 1992) will be assistant professor in the Department of Speech Communication, Drake University, Des Moines, IA. An earlier version of this essay was presented at the 1991 Speech Communication Association meeting in Atlanta, Georgia. The author wishes to thank Bruce Gronbeck, Jennifer Gunn, John Lyne, Michael McGee, and the two anonymous reviewers for their helpful comments on this essay. 
utility of recent moves to incorporate poststructuralist themes into communication studies, in general, and rhetorical criticism, in particular. I will begin, then, by situating this study within the ongoing integration of poststructuralist discourses with current rhetorical theory and criticism before proceeding to the analysis.

\section{CRITICAL RHETORIC AND RHETORICAL CRITICISM}

The past decade has witnessed an increased interest by rhetorical theorists and critics in poststructuralist forms of critique. This is most evident in the attention given to the work of Michel Foucault. Most of this attention, however, has centered on the "translation" of Foucault's ideas and those of other poststructuralist thinkers into the domain of rhetorical theory and criticism. ${ }^{6}$ This appetite for translation has, for the most part, overwhelmed the rhetorical scholar's desire and ability to move beyond a discussion of theory into critical practice. While I do not mean to disparage such theoretical work, I believe that it is essential for scholars to demonstrate the practical utility of poststructural notions by demonstrating how they can be used in critical practice.

A recent attempt to incorporate structural and poststructural views of criticism into a viable approach to rhetorical criticism is offered by McKerrow. ${ }^{7}$ He calls his approach "critical rhetoric," which refers to the practice of pulling together "disparate scraps of discourse which, when constructed as an argument, serve to illuminate otherwise hidden or taken for granted social practices." 8 McKerrow emphasizes that the practice of critical rhetoric results in the creation, rather than the explanation, of text. The focus of the critical rhetorician, then, is on the production of rhetorical discourse based on a close reading of existing documents.

McKerrow's critical rhetoric approach to criticism relies on two general concepts- the critique of domination and the critique of freedom. The critique of domination refers to an attempt to explicate how groups and individuals are oppressed and dominated by others. It is directed toward "an analysis of discourse as it contributes to the interests of the ruling class, and as it empowers the ruled to present their interests in a forceful and compelling manner." ${ }^{\circ}$ Hence, for example, a critique of domination might attempt to uncover the ways in which contemporary discourses concerning Affirmative Action policies continue to marginalize "minority" groups and, ultimately, continue their oppression. The role of the critical rhetorician, then, would be to uncover the ways in which power is expressed in such cultural statements and, more importantly, to intervene and subsequently aid in the creation of a situation with more equitable power relations.

The critique of freedom, according to McKerrow, accompanies the critique of domination in the production of critical rhetoric. It represents a philosophical position or attitude that is adopted by the critical rhetorician and is characterized by a "never-ending skepticism" that leads to a desire for "permanent criticism." 10 In incorporating the critique of freedom with the critique of domination, the critical rhetorician is obliged to treat all judgments of power relations, domination, and oppression as temporary and contingent; it does not allow the critic to be content with the new conditions or new relations of power that have been created or influenced by his/her criticism. The critique of freedom is, in essence, the postmodern move in McKerrow's approach to rhetorical criticism. It forces the critical rhetorician to recognize that there is no way to avoid relations of power and hence, no way to put an end to domination. At best, the critic can help to shift power relations and, in so doing, temporarily alter the terms of domination. 
Applied to the analysis of Affirmative Action policies, then, the critique of freedom requires the critical rhetorician to continuously re-examine and re-evaluate the merits of his/her conclusions regarding the ways in which Affirmative Action policy statements marginalize "minority" groups and thereby continue their oppression.

The critical framework employed in this essay is an amended version of McKerrow's approach to the production of critical rhetoric. This framework, which is discussed in greater detail in a recent essay by Kent Ono and $I,{ }^{11}$ requires the critic to meld the critiques of domination and freedom into a single perspective on criticism. As such, the critic must first situate him or herself within his or her own culture and cultural constraints; and having done so, posit critiques with a telos in mind, "as if the direction chosen by the critic ... were Truth with a capital ' $T$.' Upon lifting pen, however, the critic must relinquish this 'Truth' in favor of a skepticism." 12 In this view, the critic gathers disparate fragments of discourse from within a culture and works "out an interpretation, a reading of a certain reality, that might be such that on one hand, this interpretation could produce some of the effects of truth; and on the other hand, these effects of truth could become implemented within possible struggles." 13

In this essay, I have chosen to apply this critical framework to the current public discourse on the topic of alternative punishments. The fragments of discourse that I rely on to create my interpretation come from a comprehensive survey of newspaper and popular journal articles on the topic of alternative punishments published between 1985 and $1990 .{ }^{14}$ Three specific questions guide my examination of these discursive elements: (1) What is the purpose of punishment as it is now constructed? (2) What is the discursive space being created for "criminals?" and (3) What are the implications of these constructions on those who are imprisoned, or on those who avoid punishment by disciplining themselves to play within established norms? The answers to these questions serve as the bases for my interpretation of how the concept of "alternative punishment" is being rhetorically constructed in our culture.

The central claim advanced in this essay is that our society's understanding of the concept of alternative punishments emerges from the interstices of three pairs of arguments concerning the "proper" framing of criminal punishment. These pairs of arguments can be summarized as follows. First, while many agree that the traditional system of incarceration employed in this country is an ineffective means of punishing criminals, the reason for this failure is disputed. There are those who argue that the failure lies in the system's unwillingness to incarcerate criminals "long enough," while others attribute the failure to the system's role as a "graduate school of crime" where inmates learn new values, methods, and schemes that only serve to facilitate their return to crime. Second, the nature of the "criminal" itself is disputed. Criminals are alternatively depicted as misguided human beings in need of human aid and understanding, or as inherently flawed, less then human, individuals incapable of complete rehabilitation. Third, the solution to the crime problem is framed either as the need for tougher punishments and lengthier prison terms, or more effective (and humane) methods to assure the proper rehabilitation of misguided fellow humans.

These three pairs of arguments, in effect, constitute two opposing philosophical views of the criminal—one seeing him/her as basically misguided, and therefore completely rehabilitable, and the other viewing him/her as inherently flawed and therefore incapable of complete rehabilitation. The remainder of this essay elabo- 
rates on the three pairs of arguments, and the two opposing philosophical positions underlying them, in an effort to illustrate how they serve to shape and constrain our construction and presentation of alternative forms of punishment. I believe critiques of this kind will become increasingly valuable and necessary as current economic factors encourage the development and utilization of alternative punishments.

\section{THE FAILURE OF THE INCARCERATION SYSTEM}

In his critique and analysis of disciplinary systems, Michel Foucault observes that in the early 1840 s, French prisons were persistently criticized for their failure to reduce crime rates. Indeed, crime rates were not falling, recidivism remained steady, and "criminals" were creating networks of loyalties while imprisoned together. Further, the use of terms such as "delinquent" and "convict" to brand "former" lawbreakers made it more difficult for these subjects to return to "normal" society. ${ }^{15}$ Foucault claims that such criticisms led reformers to assert either that punishment was not being fully implemented or, in an overzealous attempt at total reform, to ignore punishment altogether. These same arguments, he contends, are destined to resurface as long as imprisonment is the major form of punishment.

Indeed, Foucault's prediction appears to be confirmed in contemporary discourse on current disciplinary systems used in this country. The "failure" of the present penal system is attributed either to excessive leniency extended toward those who commit crime, or to the role that prisons play in teaching inmates to become better criminals.

Arguments characterizing the current penal system as too lenient typically focus on the brevity of prison sentences. ${ }^{16}$ James R. Klauser, chief advisor to the Governor of Wisconsin, argues that "If the courts are going to be sentencing people for longer terms and more serious crimes, the solution can't be to let them out sooner." 17 A Boston based judge explains that she refuses to allow criminals out of prison before their full terms have been served because shortened terms are almost always causally connected to future legal abuse; criminals cannot "learn their lesson" with short stays in prison. ${ }^{18}$ Early release is also thought to send mixed messages to criminals and non-criminals alike. Edward Baumann, police chief of the village of Pewaukee notes, "I don't think we should step in and talk about early release before we consider everything else ... we're going to confuse society as to how we're going to deal with them." 19

Testimony from inmates and former inmates illustrates a recurrent consequence of a penal system that releases offenders before their full sentence is completed. "Criminals" implicate themselves as products of a system that not only minimally punished them, but also failed to "teach them their lessons." A twenty-year-old prisoner, identified as a Washington cocaine dealer back from his first one-year sentence, observes that "the penalties are the last thing you think about." 20 Following similar logic, an investigator of the prison crowding problem asserts that "in gang-plagued south central L.A., the word on the street is to turn yourself in if you're wanted for anything but a serious crime: L.A. County's Jail system is bursting at the seams and the prospect of a long stretch behind bars is remote."21 The implication is, of course, that if criminals served adequate tenures in prison for their first offenses, a recidivism problem would not exist. Moreover, media presentations of sensationalized crimes committed by former inmates (such as the 
Willie Horton case) are used to support the claim that those who are released from prison prematurely immediately return to a life of crime.

A dialectical tension is created by opposing arguments that characterize prisons as little more than "graduate schools of crime"-places where people go to learn "to become failures." 22 Expositions of prison overpopulation frequently note that more than 70 percent of the typical prison population are repeat offenders and the chances of a third return to prison are almost as great. ${ }^{23}$ Indeed, Nevada State Prison Director George Sumner claims that the failure of the prison system is due to excessively severe punishments for certain types of criminals. He argues that because both violent and nonviolent criminals are often assigned to the same penal institutions, non-violent criminals learn "violence." Sumner essentially argues that placing non-violent criminals in prison with their violent counterparts actually "causes" their return to society in a much hardened (and dangerous) form. ${ }^{24}$ Similarly, Kip Kautzky claims that if former convicts are not provided with rehabilitation counseling before their release, the knowledge they pick up in prison will encourage future criminal activity: "The way we are doing it is close to irresponsible. We put them on a greyhound bus with 100 dollars in their pockets, cross our fingers and hope they have the survival skills to make it on their own." 25 The only skill gained in prison is that of "criminality."

The problem of recidivism, then, has been accounted for in two apparently contradictory ways: Either "delinquents" and "criminals" return to prison because their punishments are too lenient to teach them "their lessons," or the prison environment provides prisoners with the opportunity and means to learn the norms and practical skills of criminal behavior. These opposing positions essentially reflect divergent social constructions of "prisoners," the functions prisons serve, and how alternatives to punishment are framed.

\section{THE HUMAN AND THE OTHER}

The second pair of arguments is closely related to the first. We find that those who argue against early release also tend to portray the prisoner as more-or-less inhuman in nature. Arguments of this type serve as the basis for defenses against charges that prison conditions are often unfit for human occupants. Indeed, when the city of Boston was accused in 1988 of maintaining prison conditions that contributed to "cruel and unusual punishment," city and prison officials were rhetorically placed in a position of having to defend prison conditions by depicting the prisoners as "not human." In effect, Boston officials argued that the so-called "inhumane" conditions of their prisons were actually superior to the living conditions that their prisoners had to endure in their "normal" lives. As one individual put it, prisoners "get three meals a day, most get better medical attention than they ever had, they get education, and we're doing all the things we're supposed to do." 26

Arguments are also advanced that directly deny the necessity of improving prison conditions: "The concept that all criminals can be rehabilitated has been discredited and there is a core of sociopaths who can't be changed, only held out of the community until they are past their high crime years." ${ }^{27}$ Labeled as being incapable of full rehabilitation, the criminal is seen as a wild and unruly animal who has no potential for, and therefore no need of, redemption. In Connecticut, a state experimenting with early release systems, Correction Commissioner Larry R. Meachum asks, "How would you like your entire reputation and career to be 
hanging in the balance of 2,300 losers on any given day?" 28 His question poignantly and succinctly constructs a simple fact about contemporary society: Those arrested and successfully prosecuted for crimes emerge from sentencing not simply as "convicted criminals," but also as "losers" who are unable to cope in "normal" society.

Arguments that cast the criminal as someone less than human are in conflict with arguments that call for the reincorporation of the criminal into the human family. As Kip Kautsky observes: "The focal point is what happens when an inmate is released. The community has to be served but we're talking about a guy's life."29 We often find that at least the "nonviolent" portion of the prison population is constructed as fundamentally misguided human beings. ${ }^{30}$ In such cases, inmates are often brought forth to attest to their own humanity. Jose Martinez, a resident of an overcrowded prison, is described as a hardworking student studying English in order to make his reentry into society an easy one; he desires a "normal" job on the outside upon his release. Martinez's testimony depicts the current prison system as working against his attempt to normalize himself and cultivate his humanity. Of his struggles to learn English, Martinez notes: "To study is too hard . . . There are too many people. I think this is against the law to have all these people in here." 31 Through Martinez, prisoners are constructed as industrious humans being legally denied the opportunity to exercise their humanity.

The difference between violent and non-violent criminals is often emphasized to argue that only violent criminals should spend any time in prison. Donald Murray, Legal Representative of the National Association of Counties, testifies that certain criminals "are not dangerous. There are a lot of community options that need to be developed for prisoners who present no threat to community." 32 Colorado Governor Roy Romer clearly delineates two types of criminals, those who are violent and cannot be reformed and those who are non-violent and are a "safe bet" for rehabilitation programs. ${ }^{33}$ The non-violent segment of the prison population is, in fact, symbolically tied to the "human" segments of society: "When a nonviolent middle class white offender comes up for sentencing, judges and the public readily accept the idea that an alternative, like community service, is a good idea ... Why can't the same thing be true for many of the poor thieves and burglars who fill our prison warehouses?" 34 In this bifurcation, then, prisoners essentially gain or lose their humanity based on the the way we rhetorically construct the severity of their crime.

\section{PUNISHMENT OR REHABILITATION}

The third pair of arguments regarding punishment systems parallels the first two. Arguments that depict criminals as inhuman, and claim that recidivism is the result of inadequate punishment, also call for more stringent sentencing policies as the only effective solution to problems of crime. Alternatively, arguments that depict criminals as misguided humans who only learn to commit crimes more efficiently as a result of their inappropriate or unduely long prison sentences, call for alternative forms of punishment.

Arguments against early release usually assert that heftier prison sentences are the only feasible way to reduce the frequency of crimes. Such a view is exemplified in the notion that "in order to preserve the threat of punishment for lawbreakers," it is necessary to build more prisons and enforce lengthier sentences; otherwise, "criminals" will have no incentive to cease their "lives of crime." 35 Furthermore, 
rehabilitation is a non-consideration from this perspective- punishment alone is what is required. Hence, former California Governor Deukmejian found the argument for more prison space to be an effective political strategy against his Democratic opponents. Deukmejian, depicting the currently overcrowded prisons as powder kegs on the verge of spontaneous explosion, describes a very dangerous future scenario that can only be avoided if Democrats are willing to appropriate funds for new prisons. He warns his opposition that they alone will bear the responsibility for felons who, upon early release, turn to bloodshed in the streets. ${ }^{36}$ Again, the need for rehabilitation into "normal" adult life is moot since "proper" behavior is inconceivable-that is, fugitives of all types are expected to immediately turn to crime, rape, and murder upon release. ${ }^{37}$

Arguments of this type create scenarios having only one workable solution. Deukmejian, for instance, presents his constituents with a problem that has the creation of more prison space as the only viable course of action. In fact, criminologist Franklin Zimring testifies that "the increased visibility of the justice system makes the political risks of being visibly lenient on convicts substantially higher than the risks of being ostensibly tough." 38 A rhetorical reality has been created in which "criminals" are viewed as high risks in rehabilitation programs. This rhetorical reality also portrays lawmakers as too lenient on criminals, and presents prison systems as persistently ineffective in reducing recividism.

A problem arises, however, because lengthier sentences are being legislated for the "prisoners" of the war on drugs while prisons are being simultaneously deemed ineffective. While those who support lengthier prison sentences have created an argument that leaves little room for alternative solutions, economic conditions are making alternative sentencing programs a necessity; the needs of the symbolic and the economic worlds are in conflict. As a result, justification and rhetorical construction of alternative forms of punishment as replacements for prison terms must be constructed as both punishment and rehabilitation, treating the criminal as both human and inhuman at the same time, in order to show that these systems punish "hard" enough but also "teach" criminals enough to prevent recidivism.

The rhetorical ground does, of course, exist for the inclusion of rehabilitation as an important element of disciplinary systems. An advisor to the U.S. Justice Department notes, for example, that "when people get upset because people don't go to jail, then it's pretty clear to me the focus is on punishment. But the public also is not for punishment without rehabilitation." 39 Moreover, Tony Travisond of American Correction Institutions provides another aspect of this tension in observing that "the prison cell is a very costly situation and no one should go in it unless he commits a heinous act, is a career criminal, or repeat offender." 40 In short, the clashing of urges for punishment and rehabilitation, combined with the economic pressures for alternative forms of punishment, establish the rhetorical battleground on which the solution emerges. The principal rhetors in this struggle include institution representatives, judicial officers, and even criminals themselves.

Recognizing the need to make alternative punishments palatable to legislators and the public at large, institutions responsible for such alternatives present them in a form that highlights the need to integrate punishment and rehabilitation. When alternative punishment programs are proposed and utilized, they are often given names such as "Community Penalty Program" that emphasize the "punishing" aspect of the programs, while downplaying the notion that such 
alternatives are an "easy ride" for criminals. ${ }^{41}$ Herbert Heltuer, Director of the National Center for Alternatives, observes that his principal problem in getting people to accept alternative punishments is a rhetorical one: "We're all against crime," he notes, "but we need to convince people that there are other ways to get justice." 42 Further, the public's perception of prison as the only acceptable form of punishment is labeled by one official as "dangerous": "Punishment begins with any denial of freedom; it doesn't have to include incarceration in a jail or prison." 43

Those who have sentenced criminals to alternative forms of punishment suggest that these alternatives are effective because they force criminals to confess publicly to their transgressions. In this way, criminals are inadvertently used by the court system to define for society, what will and will not be accepted, as well as what is and is not moral behavior. For example, an Albany, Oregon man, who failed to appear in court on charges of theft, was required to take out several ads in the local newspaper admitting his crimes and apologizing to the community. The District Attorney who asked for that particular alternative punishment asserted that he wanted to make the punishment "more direct, more public, and more embarrassing." 44 Similarly, in Florida, those convicted of driving under the influence of alcohol are required to display a red and white glow-in-the-dark bumper sticker that reads: "Convicted DUI Restricted License." The judge who initiated this program notes that "If reputation is such a big thing, then maybe this can be a deterrent. Public humiliation is one of the big things that has been overlooked." 45 Each of these examples represents an alternative punishment that forces the criminal to place his or her crime before the public, ask for their forgiveness, and present the crime as a concrete representation of behavior that will not be tolerated by society.

Offenders who have undergone alternative punishments often testify to their effectiveness. While Maria Arnford speaks of the electronic monitoring system as "the parent she never had," others construct out of such programs a harsh parental surveyor who shapes them once again into productive and healthy citizens. A 19-year-old who violated his probation and was subsequently sentenced to serve time in a Georgia "bootcamp" asserts, "When I came through the front door, I had become a man in about 30 seconds. I wish I had come here the first time I got in trouble." 46 After undergoing a program that forced an 18-year-old to maintain steady employment or return to prison, the young man declared after his first promotion, "I felt so proud. I went and told my mother and she felt better, like, you know, maybe now I can get a new start." 47 This program is thus portrayed as providing the individual with not only a new start on life, but also reuniting him with his family as well. In effect, then, the testimonies of criminals who have participated in various alternative punishments serve to rhetorically construct these alternatives as "rehabilitating criminals" and "moving them toward being more responsible citizens."

\section{CONCLUSIONS}

A long tradition of critical theorists have attempted to understand and explain the relationship between mass mediated forms of communication and human behavior, noting alternatively its potentially dominating, liberating, or altering influence on subjects. Horkheimer and Adorno warned of the impending ideological grasp of the culture industries. ${ }^{48}$ Marcuse argued that television and radio advertising would create repressed needs, invading individuals in their homes in 
order to dictate behavior and action. Fiske and others have taken optimism in the subject's ability to read potentially liberating messages in mediated events; Condit has questioned the limits of liberation through such reading. ${ }^{49}$ Foucault has abstracted the argument to a larger cultural level in asserting that our society has increasingly become a carceral one; a "panoptical" society in which a normalizing gaze is persistently directed on each of us. He maintains that we learn to act as instruments of the gaze, disciplining each other for abnormal behavior. We are each normalized through standardized tests, rating systems, confessions, television shows, and interpersonal cues. ${ }^{50}$ We tightly constrain what behavior we will accept from each other and hence, tightly constrain what we as a "people" will be.

Building from this notion, Poster has investigated the potential of new communication technologies to act as systems of surveillance. Combining his interest with Baudrillard's account of the effects of new communication instruments (e.g., computers, television, credit systems), Poster warns that we may have entered the age of the "Super Panopticon;" an age in which the use of surveillance is elevated to a level where resistance is impossible. ${ }^{51}$ With information about phone calls, library books, credit usage, and everyday choices all recorded by computers, it is far easier for the subject to be monitored. In effect, his/her spatial, temporal, and personality changes can be noted immediately and simultaneously. If Poster's notion contains any degree of truth, the importance of an investigation of the rhetorical positioning of these new technologies as they pertain to actual forms of discipline and punishment is a high priority. In the case of electronic home monitoring devices and urine testing, for example, the publication of Marie Arnford's childlike adoration is a telling one. Marie Arnford welcomes Poster's Super Panopticon, a system that persists in watching her every move, including monitoring her bodily intake, as a welcome parental influence. She, in effect, testifies to the virtues of George Orwell's "Big Brother."

If we hold that there are no true "selves," only discursively created subject positions, the implications of the public presentation of Arnford's adoration of the parent become clear. As Charland notes in his study of the peuple quebecois, it is only after a position is created discursively and publicly that individuals can "take on" that position. By agreeing to take on the name "quebecois," for example, a subject agrees to take on its meanings, to become an example of the term, to become an effect of the discourse. ${ }^{52}$ The implications and conclusions of this investigation, then, must necessarily comment on the ways in which the rhetorical construction of alternative systems of punishment encourage us to willingly take on the subject positions and morals being offered within the culture of the Super Panopticon.

If we are to accept the constructionist assertion that a concept is as a concept does, ${ }^{53}$ this essay becomes a theory of punishment in our society; a theory, moreover, with frighteningly pervasive implications. Through the dialectical tensions that surround our carceral system, the new discourse of punishment emerges. The first practical conclusion to be drawn from this investigation is the support it provides for what some have argued to be a breakdown of the public and private spheres through the intervention of the "state." Offe notes that the "state," through its public health programs, attempts to prescribe for individuals what can and cannot be eaten, how much sleep is necessary, how much alcohol can be consumed, etc. ${ }^{54}$ LaClau and Mouffe, positing the post-structural view of subjectivity as the creation of discursive articulations, are concerned with how all public discourse influences the way we constitute our "selves." 55 The importance of this 
study, therefore, lies not in outlining the specific details of our contemporary construction of the criminal and his/her appropriate punishment; but instead, in illustrating how rhetorical and economical pressures have combined to construct alternative forms of punishment that ask everyone to endorse the disciplinary systems of the state. That is, these constructions are seen as necessarily moving each of us, both morally and physically, away from delinquency and toward a "normal" and "correct" way of life.

Second, the fact that those who are presented with and undergo alternative forms of punishment praise their virtues, and express regret that they did not experience it sooner, provides the basis for potentially frightening implications on the question of resistance. I do not deny that a system of home monitoring and urine testing could potentially change the patterns of a drug offender's life "for the better." However, by rhetorically presenting such punishment treatments as guardians (or "parents") to be happily submitted to, resistance to domination appears questionable at best. The testimonies of those who have undergone alternative punishment programs provide evidence that, at the very least, they wish to constitute their "selves" according to the "state's" definition of normality after having gone through the programs. These individuals are more likely to deem their previous worldviews as warped, while viewing those of the parental program as closer to what is truly "right." If we are incapable of recognizing that judgments of "normality" are inherent in legal definitions of right and wrong; and instead, see it as natural and something to be desired, there is little or no chance for resistance. It is only when we know or can be shown that normalization is taking place that resistance is possible. The most problematic move in this emerging construction of punishment, then, is that it presents itself as a process almost to be desired. Considering that many of the alternative forms of punishment are contingent on electronic home monitoring, Dubiel's claim that television monitors have become a far reaching extension of Horkheimer and Adorno's culture industry rings true. ${ }^{56}$

Third, if those who already abide by social laws witness "outlaws" testifying to the benefits of the prison system in incorporating them back into society, the law abiding citizen is more likely to view his or her own behavior as unquestionably more agreeable, natural, and appealing. After all, those who are subjected to systems of punishment testify that the system is useful, providing the discipline they need and making them more responsible. No one is left unaffected by disciplinary procedures when they are constructed in this light. Even those who stand outside of formal systems of punishment are forced to confront the notion that disciplinary procedures as a whole are for their benefit. By staying within the law, we are behaving as we should. Just as children tend to view their parents as omnipotent during the socialization process, so does the discourse of punishment encourage us to view the repressive and ideological state apparatuses as not only natural, but also as a loving attempt to facilitate the return of the prodigal son.

In regards to the work of rhetorical critics, this essay points to several other conclusions. First, as I noted earlier, much of the work done in communication studies utilizing concepts borrowed from Foucault and poststructuralism, in general, has been limited to theoretical translation. This essay and others, most notably LaFountain's analysis of the discourse of Dr. Ruth, illustrate the fertility of transforming poststructuralist discourse into "creative" criticism. ${ }^{57}$ That is, it is rare to find critics utilizing theoretical works in an attempt to actually "do" 
poststructuralist critique. Instead, we have witnessed a number of arguments over the meaning and relative import of poststructuralism. If one of our tasks as rhetorical critics is to provide critiques of our social world, we must at some point utilize our interpretations of theory in order to bring forth these critiques. An essay like this one helps illustrate that such a critique does offer benefits that differ from more established perspectives. Indeed, this essay illustrates, by example, how those who study communication have implicit ties to poststructuralist discourse theories.

Second, as Condit notes, studies of this kind point to the importance of diachronic analyses that include the discourses of various perspectives and voices. ${ }^{58}$ That is, rather than attempting to follow individual speakers who are predetermined to be important, a "critical rhetoric" perspective encourages an examination of changes that occur in discourse over time and that emerge culturally rather than from individual speakers. It encourages the critic to look at a variety of discourses in an attempt to "gather fragments" and generate a narrative of the creation of the discursive objects under study. Such criticisms force us to move toward comprehensiveness in the collection of cultural fragments in order to see how alternatives to punishment arise in and through the "rules" of discourse concerning punishment in general. This gathering of fragments is, in effect, the contemporary theory of alternatives to incarceration. The concentration is less on the question "Who is talking about alternatives to punishment?" and more on the question "What are alternatives to punishment?" While this is not the only question the critic might ask, it is one that provides us with fairly clear and interesting insights. In this particular case, it illustrates that as a culture we might wish to put more thought and concern into our responses to the question of alternative punishments.

\section{NOTES}

\footnotetext{
" Outside the Walls," People Weekly, 1 February 1988, 23.

2John Dilulio, "Punishing Smarter," The Brookings Review, Summer 1989, 3-12.

${ }^{3}$ The use of the term or concept "state" is indeed a problematic one. By taking a constructionist view of social problems and social concepts, I refuse to give to the "state" a solid, objective identity but rather wish to identify its "structurated" essence. I am tempted to place the term "state" within parentheses throughout the essay in order to illustrate its rhetorical and symbolic nature. Goran Therborn has noted that when the ruling class rules, "It reproduces the economic, political, and ideological relations of its domination" (161). It reproduces itself through its ability to constitute cohesion between classes in a given social formation and to collapse contradictions. Although I do not see the state as structurally determined, it is less an entity than a process, a process that can only be seen in the operation of what Althusser has called ideological and repressive state apparatuses. Henceforth, when I refer to the "state," I wish to call up the totality of sites and actions that hegemonically compose the discursive field in which we constitute our "selves" and our "norms." For a discussion of these concepts, see Goran Therborn, What Does the Ruling Class Do When It Rules? (London: Verso, 1978), 219-40; Louis Althusser, "Ideology and Ideological State Apparatuses (Notes Toward an Investigation)," Lenin and Philosophy and Other Essays, trans. Ben Brewster (New York: Monthly Review P, 1971), 127-86; Ernesto Laclau and Chantal Mouffe, Hegemony and Socialist Strategy: Towards a Radical Democratic Politics (New York: Verso, 1985), 93-148.

${ }^{4}$ See, e.g., Bill Turque, "Why Justice Can't Be Done: America's Courts and Prisons are Overwhelmed," Newsweek, 29 May 1989, 36; Lindsey Gruson, "More and More, Prison is America's Answer to Crime," New York Times, 26 December, 1989, 4; Janet Williams, "1,100 New State Prison Cells Not Enough, US Court Told," Pittsburgh Press, 9 June, 1989.

${ }^{5}$ For an interesting anthology of case studies of social issues from a constructionist perspective, see Joel Best, ed., Images of Issues: Typifying Contemporary Social Problems (Hawthorne, NY: Aldine de Grutyer, 1989).

${ }^{6}$ See, for example: Carole Blair and Martha Cooper, "The Humanist Turn in Foucault's Rhetoric of Inquiry," Quarterly Journal of Speech 73 (1987): 151-71; Dilip Parameshwar Gaonkar, "Foucault on Discourse: Methods and Temptations," Journal of The American Forensic Association 18 (1982): 246-57; Carole Blair, "The Statement: Foundation of Foucault's Historical Criticism," Western Jourmal of Speech Communica-
} 
tion 51 (1987): 364-83; Sonja K. Foss and Ann Gill, "Michel Foucault's Theory of Rhetoric as Epistemic," Western Journal of Speech Communication 51 (1987): 384-401; Sonja K. Foss, Karen A. Foss, and Robert A. Trapp, Contemporary Perspectives on Rhetoric (Prospect Heights, IL: Waveland, 1985), 189-212; David J. Sholle, "Critical Studies: From the Theory of Ideology to Power/Knowledge," Critical Studies in Mass Communication 5 (1988): 16-41. ${ }^{7}$ Raymie E. McKerrow, "Critical Rhetoric: Theory and Praxis," Communication Monographs 56 (June 1989): 91. ${ }^{8}$ McKerrow, 101.

${ }^{9}$ McKerrow, 93.

${ }^{10}$ McKerrow, 96.

${ }^{11}$ Kent A. Ono and John M. Sloop, "Commitment to Telos: A Sustained Critical Rhetoric," Communication Monographs 59 (1992): 48-60.

${ }^{12}$ Ibid 53.

${ }^{13}$ Michel Foucault, "Clarifications on the Question of Power," Foucault Live, trans. James Cascaito, ed. Sylvere Lotringer (New York: Columbia U, 1989): 192.

${ }^{14}$ The discourse I analyzed in this study were all those articles listed in "Newsbank" and "Infotrac" dealing with alternative systems of punishment. For another justification of this choice of documents, see Celeste Michelle Condit, Decoding Abortion Rhetoric: Communicating Social Change (Urbana: University of Illinois Press, 1990): 220-1. Further, for another theoretical justification of this type of study, see Michael Calvin McGee,

"Not Men, But Measures: The Origins and Import of An Ideological Principle," Quarterly Journal of Speech 64 (1978): 141-54.

${ }^{15}$ Michel Foucault, Discipline and Punish: The Birth of the Prison, trans. Alan Sheridan (New York: Pantheon, 1977), 264-8.

${ }^{16}$ For examples, see Sarah Sturman, "Prisoners Jamming Jail Once Again," Cincinnati Post, 1 October, 1986; Adam Weintraub, "To Build or Not to Build?," Arkansas Gazette, 25 April, 1989; Gruson.

${ }^{17}$ Steve Schultze, "Governor Prefers More Prison Space," Milwaukee Journal, 26 May, 1989.

${ }^{18}$ Sheeley Murphy, “Judge Vows 'No Release for Big-Time Drug Kings,' Boston Herald, 4 September, 1988.

${ }^{19}$ Schultze, "Governor Prefers."

${ }^{20}$ Turque, "Why Justice Can't Be Done." Emphasis mine. It is interesting to note, however, that the author's description of his sentence as his first already assumes that the drug dealer will return to jail again. ${ }^{21}$ Ibid.

${ }^{22}$ Chris Woodka, "Kautzky Seeks New Thrust in Keeping Cons Out of Jail," Pueblo Chieftan, 2 October, 1988.

${ }^{23}$ DiIulio, "Punishing Smarter," 4, 8; Ann Crittenden, "Prison Can Be a Dumb Solution,” New York Times, 29 December, 1989.

${ }^{24}$ Lynne Tudhy and Kathryn Hold, "Prison Chief is Undaunted," Hartford Courant, 9 October, 1988.

${ }^{25}$ Woodka, "Kautzky Seeks."

${ }^{26}$ Pat R. Gilbert, "Overcrowding Leads to Fights, Tension, Illness," (Trenton, NJ) Times, 20 February, 1987.

${ }^{27}$ Adam Weintraub, "To Build or Not to Build?" Arkansas Gazette, 25 April, 1989

${ }^{28}$ Tudhy and Hold, "Prison Chief is Undaunted."

${ }^{29}$ Woodka, "Kautzky Seeks."

${ }^{30}$ See, e.g., Jerry Markon, “Jails Bulge in Western Tennessee: Official Says Bomb Ticks," (Memphis) Commercial Appeal, 5 July, 1989.

${ }^{31}$ Gilbert, "Overcrowding Leads."

32 Joe Morris, "A Municipal Hot Potato," American City and County, February, 1990, 29.

${ }^{33}$ Brian Weber, "Prison Terms Must Be Cut, Romer Urges," Colorado Springs Gazette Telegraph, 16

November, 1989.

${ }^{34}$ Ann Crittenden, "Prison Can Be a Dumb Solution," New York Times, 29 December, 1989.

${ }^{35}$ Weintraub, "To Build."

${ }^{36}$ Amy Chance, "Duke Says Senate Demos Risk Public Safety on Prison Issue," Sacramento Bee, 11 September, 1986.

37"Bed and Board, No Vacancies," The Economist, 21 March, 1987, 28

${ }^{38}$ Gruson, "More and More."

${ }^{39}$ Weintraub, "To Build."

${ }^{40}$ Weintraub, "To Build."

${ }^{41}$ Ted Gest, "Personalized Penalties," US News and World Report, 20 November, 1989, 75.

${ }^{42}$ Richard Lacayo, "Considering the Alternatives," Time, 2 February, 1987, 61.

${ }^{43}$ Barbara Quinn, “Jail Overcrowding: A Systems Problem," American City and County, June, $1988,78$.

44" Outside the Wall," 23.

45 Ibid. 24.

46 Ibid. 25.

${ }^{47}$ Ibid. 27.

${ }^{48}$ Max Horkheimer and Theodor Adorno, Dialectic of Enlightenment, trans. John Cumming (New York: Continuum, 1988), 239-47. 
${ }^{49}$ See John Fiske, Television Culture (New York: Methuen, 1987) and Celeste Michelle Condit, "The Rhetorical Limits of Polysemy," Critical Studies in Mass Communication 6 (1989), $103-22$.

${ }^{50}$ Foucault, Discipline, 293-308.

${ }^{51}$ Mark Poster, Critical Theory and Poststructuralism: In Search of a Context (Ithaca: Cornell UP, 1989), 123.

52 Maurice Charland, "Constitutive Rhetoric: The Case of the Peuple Quebecois," Quarterly Journal of Speech 73 (1987): 133-50; for discussions of this constitutive influence of language, see also Michael Calvin McGee, "In Search of the 'People': A Rhetorical Alternative," Quarterly Journal of Speech 61 (1975): 235-49; Michael Calvin McGee, "On Feminized Power," The Van Zelst Lecture in Communication (Evanston, IL: May, 1985): 23-25.

${ }^{53}$ In addition to the aforementioned Best anthology, see Gidden's discussion of "structuration" in Anthony Giddens, Central Problems in Social Theory: Action, Structure and Contradiction in Social Analysis (Berkeley: $U$ of Califormia P, 1979), 69-73.

${ }^{54}$ Klaus Offe, "Interview with Offe," John Keane and David Held, Contradictions of the Welfare State (Boston: MIT P, 1983), 277.

${ }^{55}$ Laclau and Mouffe, Hegemony, 162.

${ }^{56}$ Helmut Dubiel, Theory and Politics: Studies in the Development of Critical Theory, trans. Benjamin Gregg (Cambridge: MIT P, 1985), 92.

${ }^{57}$ Marc J. LaFountain, "Foucault and Dr. Ruth," Critical Studies in Mass Communication 6 (1989): 123-37.

${ }^{58}$ Celeste (Railsback) Condit, "The Contemporary American Abortion Controversy: Stages in the Argument," Quarterly Joumal of Speech 79 (1984): 422-24. 